\title{
MAINTENANCE PERFORMANCE IN THE SOUTH AFRICAN INDUSTRY
}

\author{
J.L. Jooste \\ Pragma Africa, South Africa \\ wyhanj@pragma.co.za
}

\begin{abstract}
This paper presents the results of a survey conducted on the performance of local maintenance practices. The client base of a leading asset management consultancy was used as the basis for the survey. The sample included a diversity of enterprises across the local industry. Maintenance-related data for 2004 was statistically analyzed; it is presented here in three categories relating to maintenance performance: planning and resource usage, maintenance tactics and time distribution, and performance monitoring and reporting. The aim of the results is to serve as performance benchmarks for the local industry, which will aid in setting targets and identifying initiatives for improvement.
\end{abstract}

\section{OPSOMMING}

Die resultate word getoon van ' $\mathrm{n}$ opname wat gedoen is oor die prestasie van plaaslike instandhoudingspraktyke. Die kliëntebasis van 'n toonaangewende raadgewende batebestuurfirma is gebruik as basis vir die opname. Die steekproef sluit ' $n$ verskeidenheid van ondernemings, verteenwoordigend van die plaaslike industrie, in. Instandhoudingsdata vir 2004 is statisties geanaliseer en word aangebied in drie kategorieë met betrekking tot instandhoudingsprestasie: beplanning en gebruik van hulpbronne, instandhoudingstaktiek en tydsverdeling, en prestasiemonitering en rapportering. Die doelwit is om ' $n$ verwysingspunt vir die plaaslike industrie te stel, vanwaar teikens bepaal en verbeteringsinisiatiewe geïdentifiseer kan word. 


\section{INTRODUCTION}

Maintenance plays a fundamental role in manufacturing practice, and is influenced by a variety of factors such as workforce skills and commitment, the effectiveness of business processes, and the utilization of technology. Although ample material is published on a diversity of maintenance issues, information relating to local maintenance performance and how it compares with international standards is limited.

This paper presents the results of a survey conducted on maintenance performance in the South African manufacturing industry. The objectives of the study were to determine the current state of maintenance performance, and to derive a list of performance metrics that can be used as benchmarks for self-assessment and comparison against published standards.

In the first part of the paper, we describe the survey, the sample classification, and the descriptive statistics used for presenting the metrics. This is followed by the results and interpretation of the metrics, and remarks on accuracy. Finally, some conclusions are drawn.

\section{LITERATURE}

The process of measuring and managing performance in modern business is a topical subject, and new developments in the field are continually researched. Maintenance plays an important role in supporting business processes and strategies (e.g. lean manufacturing, just-in-time), and therefore contributes to the overall performance of the business (Woodhouse [1]). The purpose of performance measurement is to provide a basis for improvement. Without measurement there is no certainty that improvement has actually been achieved. Even if there is a perception that things are better, the question to ask is: "Better than what?" (Wilson [2]).

Mitchell [3] defines the process of measuring "best practice" performance and comparing results to corporate (or maintenance) performance as benchmarking. Benchmarking can be used to answer the above question. By comparing maintenance metrics against other comparable metrics of leading organizations, information that will help to identify the strengths and weaknesses of existing performance can be obtained (Anderson and Petersen, cited by Yam et al. [4]). However, it is difficult to find comparative information that truly represents the population of which a company is part (Jooste [5]). Although benchmarks for world-class performers are available, they are limited, and in some cases (e.g. Campbell [6]) the origin is unknown or based on case studies with specific outcomes (e.g. Chin et al. [7]). Basing performance targets on these benchmarks may cause the targets to be over- or under-estimated, resulting in ineffective performance management and ambiguous improvement plans. 


\section{RESEARCH METHODOLOGY}

\subsection{The survey}

The survey was conducted on the client base of a leading South African asset management consultancy [8], and was based in the consultancy's outsourced maintenance management division, $B U R O$. The $B U R O$ operates by hosting a client's computerized maintenance management system (CMMS) and managing the system for the client. This include an up-to-date asset register, complete preventive maintenance plan, the scheduling and recording of maintenance activities, analysis of maintenance information, and recommendation of improvement initiatives. Although it could be argued that companies making use of a service such as the $B U R O$ would probably be classified as small- and medium-enterprises (SME), this is not necessarily the case. The sample population covers a wide range of enterprises of different sizes that do not all fit the characteristics of SMEs as outlined by some authors (e.g. Hudson et al. [9]).

The survey is based on monthly data collected from the CMMS databases during 2004, and covers asset management key performance areas, such as:

- $\quad$ Planning and resource usage

- Maintenance tactics \& time distribution

- $\quad$ Performance monitoring \& reporting

\subsection{The sample}

The sample of client databases was selected on two criteria:

- Uninterrupted service and data recording for the 12-month study period between 1 January 2004 and 31 December 2004.

- Implementation of the CMMS maintenance systems and procedures more than six months prior to the study period - in other words, prior to July 2003.

Based on the criteria, 42 of 110 client databases qualified for inclusion in the sample, or $38.2 \%$ of the sample population. This is not out of line with other surveys in manufacturing practice, which have shown response rates around $18 \%$ in cases where questionnaires were used (Sohal et al. [10]).

The sample has four categories. Figure 1 shows the regional distribution of the sample. The two main regions, hosting $78.5 \%$ of the sample databases, are the Western Cape (operating from Cape Town) and Gauteng (operating from Johannesburg). The rest are hosted in Kwa-Zulu/Natal and the Eastern Cape, operating from Durban and Port Elizabeth respectively.

Figure 2 shows the sample distribution classified by industry sector. This classification is based on the International Standard Industrial Classification of all economic activities (ISIC, [11]). The main sectors - 62\% of the sample - are the manufacturing of food products and beverages; quarrying of stone, sand and clay; the 
manufacturing of motor vehicles, trailers and semi-trailers; and the manufacturing of rubber and plastic products. Other manufacturing industries include chemicals and chemical products, paper and paper products, wood and products of wood and cork, textiles, architectural, engineering and other technical activities, and non-metallic mineral products.

Figure 3 shows that more than three-quarters (78.6\%) of the sample have an average maintenance workforce of between one and ten artisans. Another $14.3 \%$ have an average of eleven to fifteen artisans, while the remaining $7.2 \%$ have an average of more than fifteen artisans in their workforce.

As illustrated in Figure 4, two-thirds of the sample process an average of zero to 500 maintenance job cards per month. A further $28.5 \%$ process 501 to 1,000 job cards per month, while a further $4.8 \%$ process more than 1,000 job cards per month.

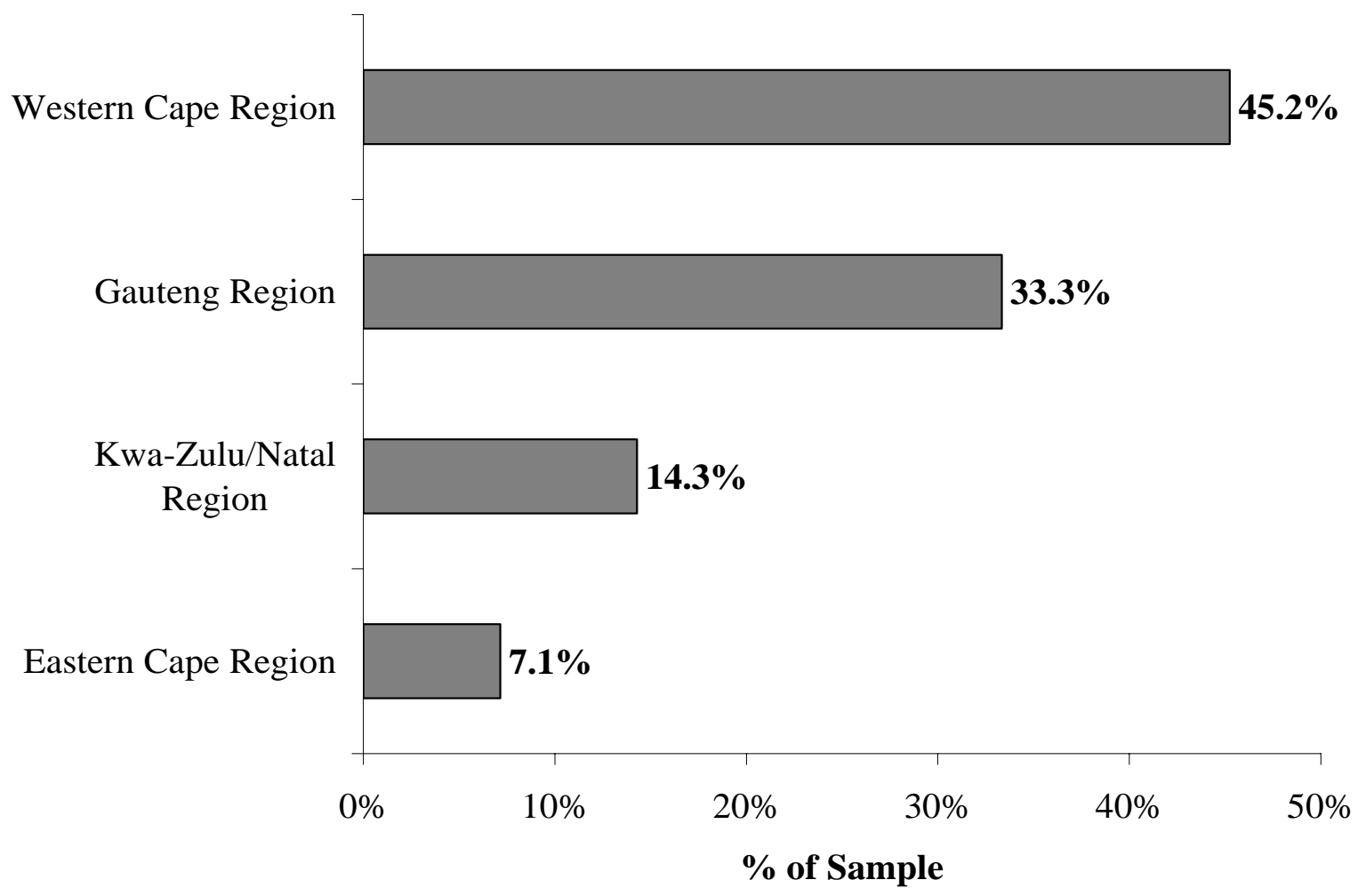

Figure 1: Sample Classification by Region 
Manufacture of food products and beverages

Quarrying of stone, sand and clay

Manufacture of motor vehicles and trailers

Manufacture of rubber and plastics products

Manufacture of fabricated metal products

Manufacture of chemicals and chem. products

Manufacture of paper and paper products

Manufacture of wood and cork products

Manufacture of textiles

Architectural and engineering activities Manufacture of other non-metallic mineral products

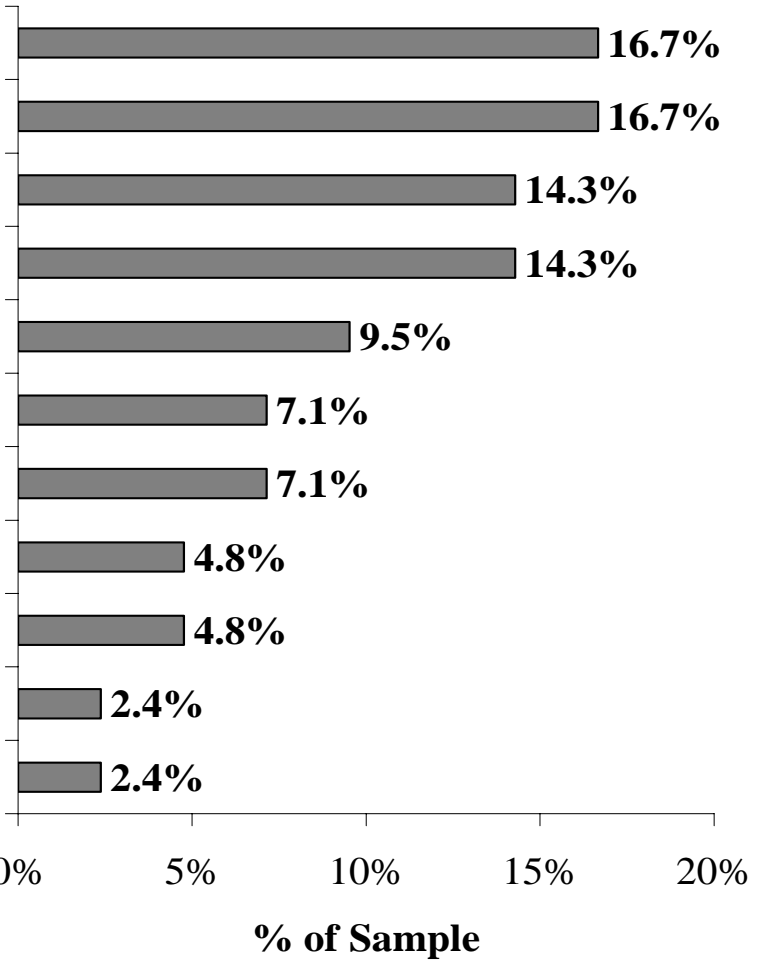

Figure 2: Sample Classification by Industry Sector

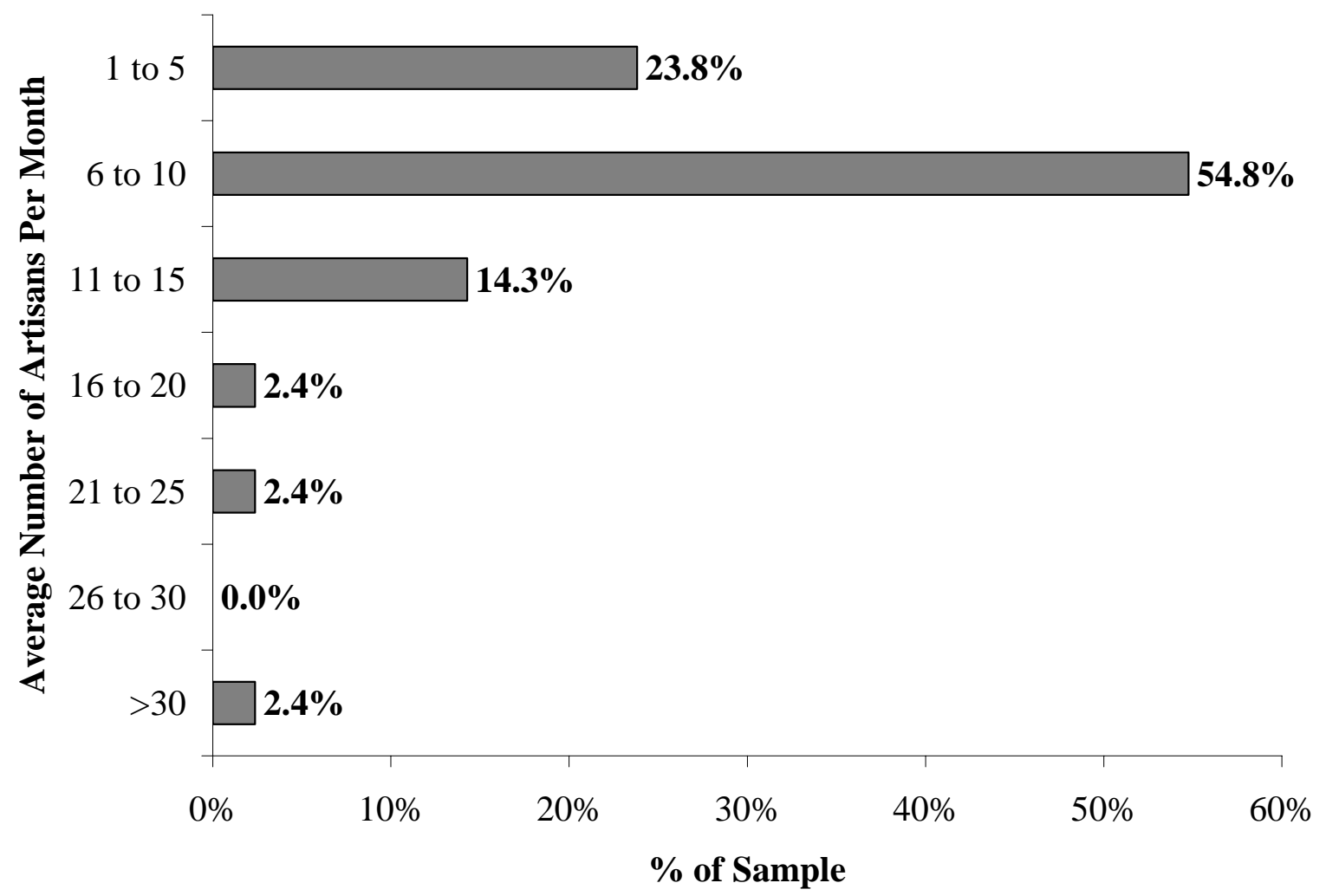

Figure 3: Sample Classification by Average Number of Artisans 


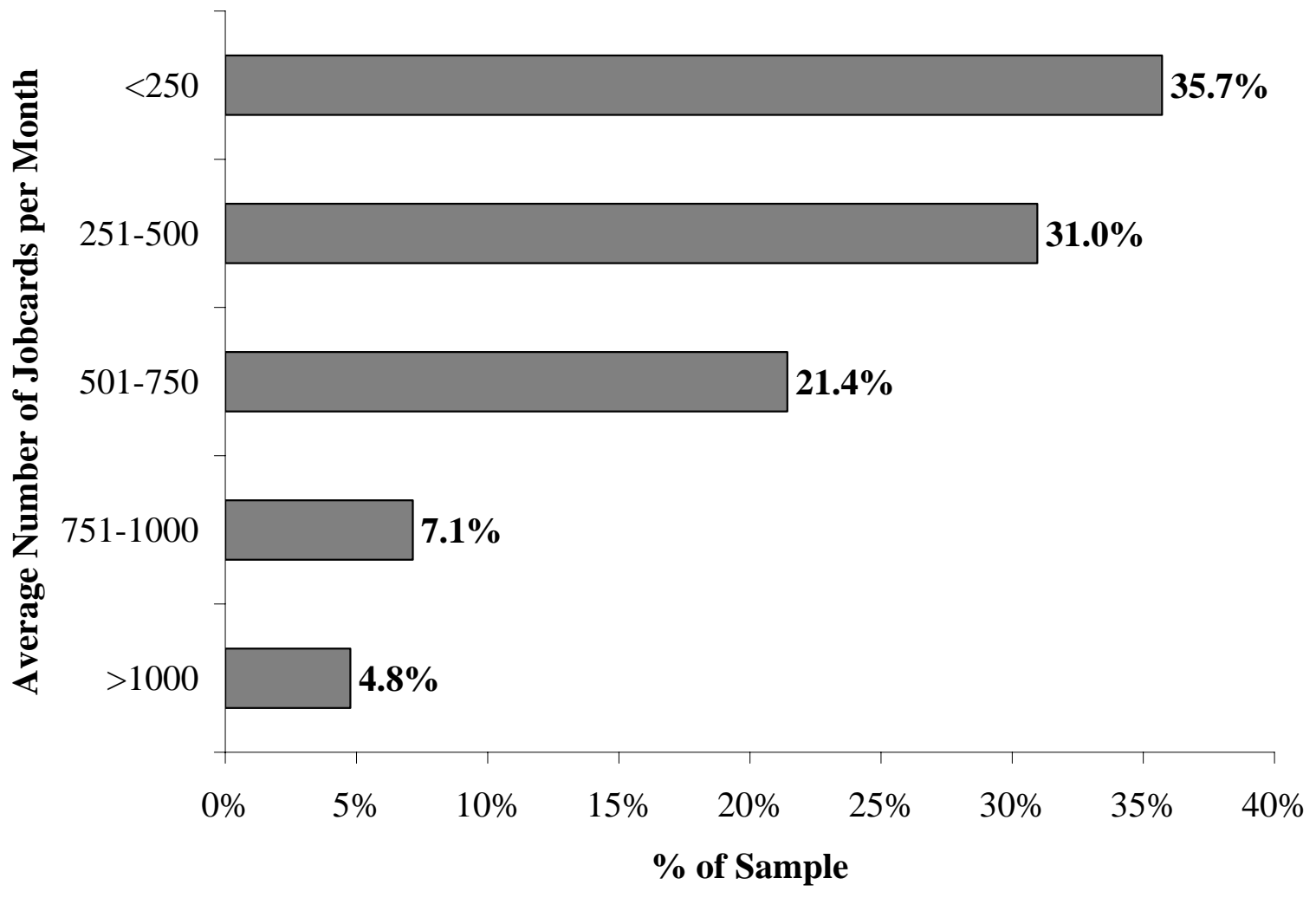

Figure 4: Sample Classification by Average Number of Job Cards per Month

\subsection{Descriptive statistics}

The data collected during the survey was taken to be distribution-free, and order statistics were used for calculation purposes. No potential outliers were removed to ensure that results were representative of the sample.

The results presented are described through descriptive statistical indicators as calculated by Keller and Warrack [12]. These include measures of location (mean, median), variability (standard deviation, coefficient of variation, minimum, maximum), shape (kurtosis - measure of peakedness, skewness - measure of symmetry) and of relative standing (percentiles and quartiles).

The percentiles and quartiles are useful, as they give detailed information on the distribution of statistics. In Tables I to III the $5^{\text {th }}$-, $25^{\text {th }}$ - (lower quartile), $50^{\text {th }}$ (median), $75^{\text {th }}$ - (upper quartile), and $95^{\text {th }}$-percentiles are listed. The $25^{\text {th }}-$, $50^{\text {th }}$ - and $75^{\text {th }}$-percentiles separate the data into four equal parts: $25 \%$ of values calculated are smaller than the $25^{\text {th }}$-percentile, $25 \%$ exceed the $75^{\text {th }}$-percentile, while $25 \%$ lie between each of the $25^{\text {th }}$-, $75^{\text {th }}$-, and $50^{\text {th }}$-percentiles. Similarly, $5 \%$ of the values are smaller than the $5^{\text {th }}$-percentile and $5 \%$ exceed the $95^{\text {th }}$-percentile (Devore \& Farnum [13]).

\section{RESULTS AND INTERPRETATION}

The presented metrics are not intended to be a comprehensive list: various other metrics are available for measuring maintenance performance (e.g. listings by Mitchell [3] and Campbell [6]). The metrics presented in this paper are chosen on 
available data with consistent definitions and calculations throughout the sample population. The metrics are presented in three categories: (i) planning and resource usage, (ii) maintenance tactics and time distribution, and (iii) performance monitoring and reporting.

\subsection{Planning and resource usage}

In Table 1 the results for the maintenance planning and resource usage category are presented. The metrics are schedule attainment, overtime percentage, job duration, hours per artisan per month, and jobs per artisan per month.

\begin{tabular}{|r|c|c|c|c|c|}
\hline $\begin{array}{r}\text { Statistical } \\
\text { Indicator }\end{array}$ & $\begin{array}{c}\text { Schedule } \\
\text { Attainment }\end{array}$ & $\begin{array}{c}\text { Overtime } \\
\text { Percentage }\end{array}$ & $\begin{array}{c}\text { Job } \\
\text { Duration } \\
\text { [h:mm] }\end{array}$ & $\begin{array}{c}\text { Hours per } \\
\text { Artisan }\end{array}$ & $\begin{array}{c}\text { Jobs per } \\
\text { Artisan }\end{array}$ \\
\hline Mean & $78.7 \%$ & $5.9 \%$ & $2: 30$ & 121 & 62 \\
\hline Standard Deviation & $16.7 \%$ & $6.4 \%$ & $1: 36$ & 34 & 38 \\
\hline $\begin{array}{r}\text { Coefficient of } \\
\text { Variation }\end{array}$ & $21.2 \%$ & $108.5 \%$ & $64.0 \%$ & $28.1 \%$ & $61.3 \%$ \\
\hline Kurtosis & 3.1 & 3.8 & 6.3 & -0.3 & 11.0 \\
\hline Skewness & -1.6 & 1.7 & 1.9 & 0.2 & 2.5 \\
\hline Minimum & $19.3 \%$ & $0.0 \%$ & $0: 00$ & 7 & 12 \\
\hline $5^{\text {th }}$ Percentile & $44.4 \%$ & $0.0 \%$ & $0: 46$ & 71 & 20 \\
\hline Lower Quartile & $74.1 \%$ & $0.8 \%$ & $1: 27$ & 96 & 38 \\
\hline Percentile/Median & $81.3 \%$ & $4.2 \%$ & $2: 11$ & 117 & 52 \\
\hline Upper Quartile & $90.3 \%$ & $8.5 \%$ & $3: 06$ & 148 & 77 \\
\hline $95^{\text {th }}$ Percentile & $98.4 \%$ & $19.6 \%$ & $5: 33$ & 178 & 123 \\
\hline Maximum & $99.6 \%$ & $41.0 \%$ & $13: 08$ & 219 & 319 \\
\hline
\end{tabular}

Table 1: Descriptive Statistics for Planning \& Resource Usage Metrics

Schedule attainment (also known as "schedule compliance" according to Campbell [6], and "planned completion rate" according to Mitchell [3]) is the percentage of scheduled tasks actually completed within a specified time from schedule. For this survey scheduled tasks are defined as predefined and planned maintenance activities that are scheduled and generated through the CMMS. The time from schedule-period is equal to 30 days. An average of $78.7 \%$ of scheduled tasks (CMMS generated tasks) is completed within 30 days of the scheduled date. Based on the upper and lower quartiles, it follows that three-quarters of the sample - about three-quarters of industry - achieve more than $74.1 \%$, while a quarter of industry is achieving $90.3 \%$ and higher. Compared with the Phillips and Lammer's benchmark of $70 \%$ for a four week period (cited by Mitchell [3]), at least three-quarters of industry meets this standard. Using Campbell's [6] higher benchmark of 92\%, the survey shows that less than a quarter of industry meets this target.

Overtime percentage is the maintenance overtime percentage of total time spent on maintenance activities. Overtime includes week-, weekend- and public holiday overtime, while total time equals normal- plus all overtime. Based on maintenance 
activity durations, an average of 5.9\% of maintenance is being done during overtime. It follows from the lower and upper quartiles that the lower quarter of industry does less than $0.8 \%$, and the upper quarter between $8.5 \%$ and $41 \%$ of maintenance activities during overtime.

Job duration is the total number of man-hours (normal- and overtime hours) required to complete a maintenance job, irrespective of the type of maintenance work. The duration of an average maintenance job is 2 hours 30 minutes. From the upper and lower quartiles it follows that the upper $25 \%$ of maintenance jobs exceed 3 hours 06 minutes in duration, while the lower $25 \%$ of maintenance tasks are completed in less than 1 hour 27 minutes.

Hours per artisan are the total number of hours an artisan records per month on maintenance job cards. On average an artisan records 121 hours of maintenance activities. Depending on the number of hours in a work week, 121 hours represent $76 \%$ utilization in the case of a 160-hour work week, and $67 \%$ utilization for a 180 hour work week. Based on the quartiles, the lower quarter of artisans record less than 96 hours per month, while the upper quarter of artisans record more than 148 hours per month.

Jobs per artisan are the total number of jobs that an artisan works on per month. On average, 62 jobs are completed by an artisan, while the lower quarter of artisans works on less than 38 jobs per month and the upper quarter on more than 77 jobs per month.

\subsection{Maintenance tactics and time distribution}

In Table 2 the results for the maintenance tactics and time distribution category are presented. Since different size companies with different resource- and capacity levels are compared, metrics presented on maintenance types are given in percentages - the number of maintenance man-hours per maintenance type per month, calculated as a percentage of total maintenance man-hours for the same month.

The following definitions were used for the different types of maintenance:

- $\quad$ Preventive maintenance consists of time-based tests, inspections, services and/or replacements conducted on regular calendar and/or operating time intervals, in order to avoid failures based on anticipated lifetime (Mitchell [3]).

- Condition monitoring ${ }^{1}$ (also known as condition based maintenance or predictive maintenance) consists of condition-based operating- and condition measurements and non-invasive tests, for identifying anomalies in advance, in order to avoid failures (Mitchell [3]).

- Safety maintenance consists of preventive- and condition-monitoring maintenance as well as unplanned maintenance activities required by safety regulations.

\footnotetext{
${ }^{1}$ Due to recording variations, preventive- and condition-based maintenance activities were grouped together.
} 


\begin{tabular}{|c|c|c|c|c|c|c|c|}
\hline Statistical Indicator & 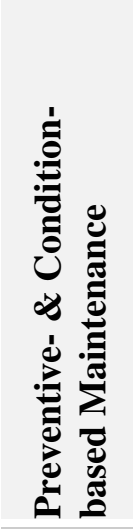 & 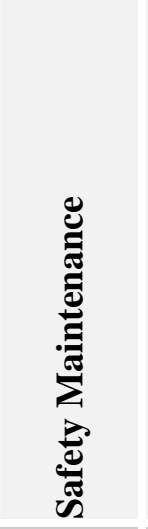 & 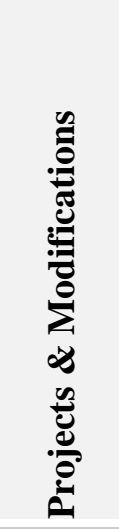 & 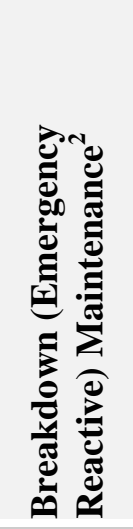 & 总 & 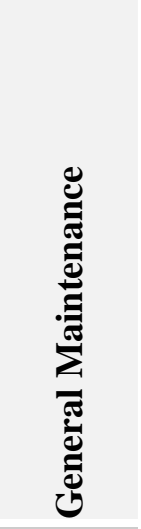 & 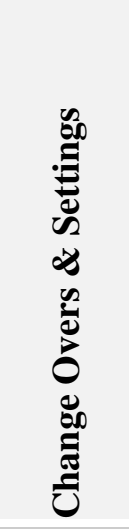 \\
\hline Mean & $24.1 \%$ & $3.1 \%$ & $7.5 \%$ & $18.0 \%$ & $29.7 \%$ & $12.9 \%$ & $4.6 \%$ \\
\hline Standard Deviation & $21.0 \%$ & $4.6 \%$ & $9.9 \%$ & $16.2 \%$ & $20.8 \%$ & $13.5 \%$ & $6.6 \%$ \\
\hline Coefficient of Variation & $87.1 \%$ & $148.3 \%$ & $132 \%$ & $90 \%$ & $70.0 \%$ & $104.7 \%$ & $143.5 \%$ \\
\hline Kurtosis & 2.7 & 6.6 & 3.0 & 0.9 & -0.1 & 2.3 & 2.6 \\
\hline Skewness & 1.6 & 2.4 & 1.9 & 1.2 & 0.7 & 1.5 & 1.8 \\
\hline Minimum & $0.0 \%$ & $0.0 \%$ & $0.0 \%$ & $0.0 \%$ & $0.0 \%$ & $0.0 \%$ & $0.0 \%$ \\
\hline $5^{\text {th }}$ Percentile & $0.4 \%$ & $0.0 \%$ & $0.0 \%$ & $0.8 \%$ & $0.9 \%$ & $0.0 \%$ & $0.0 \%$ \\
\hline Lower Quartile & $10.3 \%$ & $0.1 \%$ & $0.8 \%$ & $5.8 \%$ & $13.2 \%$ & $2.0 \%$ & $0.0 \%$ \\
\hline $50^{\text {th }}$ Percentile/Median & $18.4 \%$ & $1.1 \%$ & $3.6 \%$ & $12.3 \%$ & $26.3 \%$ & $9.2 \%$ & $1.6 \%$ \\
\hline Upper Quartile & $32.6 \%$ & $4.2 \%$ & $9.6 \%$ & $27.3 \%$ & $43.2 \%$ & $19.8 \%$ & $5.6 \%$ \\
\hline $95^{\text {th }}$ Percentile & $72.6 \%$ & $12.6 \%$ & $31.4 \%$ & $52.9 \%$ & $68.8 \%$ & $45.2 \%$ & $19.8 \%$ \\
\hline Maximum & $100.0 \%$ & $26.9 \%$ & $46.2 \%$ & $73.6 \%$ & $88.7 \%$ & $73.8 \%$ & $31.0 \%$ \\
\hline
\end{tabular}

Table 2: Descriptive Statistics for Maintenance Tactics \& Time Distribution

- $\quad$ Projects and modifications (also known as pro-active maintenance) consists of non-repetitive activities applied to equipment or the plant prior to or during operation to prevent problems, gain improved reliability, minimize failures, or improve capacity (Mitchell [3]).

- Reactive maintenance consists of corrective actions taken on failure or obvious threat of failure (Mitchell [3]). For this survey, reactive maintenance was subdivided into breakdown (emergency, reactive) maintenance, consisting of corrective actions taken on failure, and reactive (non-emergency) maintenance, consisting of corrective actions taken on obvious, unanticipated threat of failure.

- General maintenance consists of non-production related maintenance activities, which include housekeeping, cleaning, and general building and yard maintenance tasks for which the maintenance department is responsible.

- Change overs and settings consists of tasks relating to the change over of machines for manufacture of a different type and/or size of product, as well as the pre-production set-up of the machines by maintenance personnel.

On average industry spends $24.1 \%$ of total maintenance hours per month on preventive- and condition-based maintenance. From the lower quartile and $95^{\text {th }}$ percentile, it follows that a quarter of industry spends less than $10.3 \%$ on preventive-

\footnotetext{
${ }^{2}$ Similar to Breakdown Rate presented in section 4.3, Table 3.
} 
and condition-based maintenance, while $5 \%$ of industry spends more than $72.6 \%$ of its time on these maintenance tactics. A further average of $3.1 \%$ of maintenance time is spent on activities relating to safety regulations, with the lower quarter of industry spending less than $0.1 \%$, and the upper quarter more than $4.2 \%$ of their time on safety maintenance. On average industry spent $7.5 \%$ of maintenance time per month on projects and modifications. Based on the upper and lower quartiles, the lower quarter of industry spends less than $0.8 \%$, while the upper quarter spends more than $9.6 \%$ of its time on projects and modifications. All of the above maintenance types can be classified as planned maintenance (Yam et al. [4]), with a combined average of $34.1 \%$ of total maintenance time.

On average $18 \%$ of maintenance time is taken up by breakdown (emergency, reactive) maintenance (refer to section 4.3 ). An average of $29.7 \%$ of maintenance time goes into corrective actions taken on anticipated machine failures or reactive (non-emergency) maintenance. The lower quarter of industry achieves less than $13.2 \%$ on reactive maintenance, but on the other hand the upper quarter of industry spends more than $43.2 \%$ of its time on reactive (non-emergency) maintenance. General (or non-production related) maintenance takes up an average of $12.9 \%$ of maintenance time, while a quarter of industry spends more than $19.8 \%$ of its time on this type of maintenance work. The above types can be classified as unplanned maintenance, with a combined average of 58.5\%.

\subsection{Performance monitoring and reporting}

The results for the performance monitoring and reporting category are presented in Table 3. The metrics are breakdown rate, breakdown count, mean time to repair, root cause percentage, and downtime.

\begin{tabular}{|c|c|c|c|c|c|}
\hline Statistical Indicator & 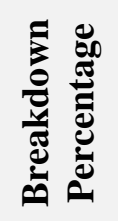 & 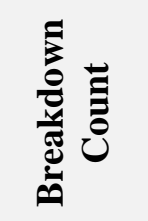 & 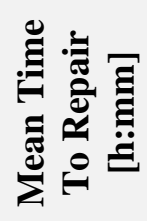 & 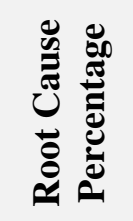 & 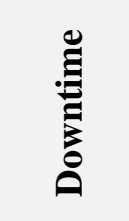 \\
\hline Mean & $18.0 \%$ & 97 & $2: 21$ & $28.5 \%$ & 288 \\
\hline Standard Deviation & $16.2 \%$ & 143 & $1: 36$ & $36.8 \%$ & 840 \\
\hline $\begin{array}{r}\text { Coefficient of } \\
\text { Variation }\end{array}$ & $90.0 \%$ & $147.4 \%$ & $68.1 \%$ & $129.1 \%$ & $291.7 \%$ \\
\hline Kurtosis & 0.9 & 10.9 & 21.8 & -1.0 & 23.0 \\
\hline Skewness & 1.2 & 3.1 & 3.5 & 0.8 & 4.7 \\
\hline Minimum & $0.0 \%$ & 1 & $0: 16$ & $0 \%$ & 0 \\
\hline $5^{\text {th }}$ Percentile & $0.8 \%$ & 4 & $0: 42$ & $0 \%$ & 2 \\
\hline Lower Quartile & $5.8 \%$ & 17 & $1: 19$ & $0 \%$ & 13 \\
\hline $50^{\text {th }}$ Percentile/Median & $12.3 \%$ & 47 & 2:09 & $0 \%$ & 48 \\
\hline Upper Quartile & $27.3 \%$ & 110 & 2:50 & $62.5 \%$ & 169 \\
\hline $95^{\text {th }}$ Percentile & $52.9 \%$ & 429 & $4: 36$ & $96.3 \%$ & 1804 \\
\hline Maximum & $73.6 \%$ & 907 & 16:00 & $100.0 \%$ & 6214 \\
\hline
\end{tabular}

Table 3: Descriptive Statistics for Performance Monitoring \& Reporting Metrics 
Breakdown (emergency reactive) maintenance, as in Table 2 column 4, is by definition the same as breakdown percentage, which is the percentage of total maintenance man-hours spent on breakdown (emergency, reactive) maintenance. On average $18 \%$ of maintenance activities are spent on breakdown maintenance. From the lower quartile it follows that the lower quarter of industry spends less than $5.8 \%$ of its time on breakdown maintenance; but also based on the $95^{\text {th }}$-percentile, $5 \%$ of industry spends more than $52.9 \%$ of its time on breakdown maintenance. It follows that a quarter of local industry is on par with benchmarks for breakdown percentage, according to Bahrami (cited by Mitchell [3]) ( 2 \%) and Yam et al. [4] ( 7\%).

Breakdown count is the number of failure occurrences per month. The difference between the mean (which is sensitive to outliers) and the median (which is insensitive to outliers) is 50 failures. It can therefore be deduced that a number of industries have very high breakdown counts that bias the mean. This is seen from the $95^{\text {th }}$-percentile (429) and the maximum (907). The median will therefore be a more suitable measure of location. From the lower- and upper quartiles it follows that the lower quarter of industry achieves breakdown counts of 17 and fewer per month, while the upper quarter of industry tallies 110 and more breakdown counts per month.

Mean time to repair is a measure of maintainability (Campbell [6]), indicating the mean time (in man-hours) to repair after a failure has occurred. On average it takes industry 2 hours 21 minutes to repair a failed piece of equipment. Based on the $5^{\text {th }}$-, $25^{\text {th }}$ - and $95^{\text {th }}$-percentiles, the lower $5 \%$ of industry repairs failures in less than 42 minutes; the lower $25 \%$ takes less than 1 hour 19 minutes, while the upper $5 \%$ of industry takes longer than 4 hours 36 minutes to repair a failure.

Root cause percentage is defined as the number of failure occurrences, formally analyzed and documented up to root cause level, as a percentage of total failure occurrences. An average of $28.5 \%$ of failed machines are analyzed to find the root cause of the failure. The median is equal to zero, indicating that there are a number of industries recording very high root cause percentages, biasing the mean. It follows that $50 \%$ of industry does not analyze to root cause level. The upper quarter of industry, however, analyses more than $62.5 \%$ of their failures to find the root causes, while $5 \%$ of industry analyses between $96.3 \%$ and $100 \%$ of their failures to root cause level.

Downtime is defined as the period of time during which a machine is not in a condition to perform its intended function (Campbell [6]). It is different from breakdown (emergency, reactive) maintenance, since it only represents the duration of lost production, whereas breakdown (emergency, reactive) maintenance represents the total man-hours spent on corrective actions on failed equipment. Downtime is recorded from a maintenance perspective (on maintenance job cards) and therefore deviations from production performance may be expected in cases where parallel measurements are recorded. Large deviations can be seen for the downtime information in Table 3. The data from the survey indicates an average of 288 hours of downtime per month, a standard deviation of 840 hours and a maximum of 6,214 hours per month! These statistics appear suspicious, but can be explained when 
compared to the median, upper quartile, and $95^{\text {th }}$ percentile. The average and standard deviation are sensitive to outliers, while the median, quartiles, and percentiles are not. Based on the variation between the ranges of the indicators of relative standing - 13 hours (first quarter), 35 hours (second quarter), 121 hours (third quarter), 6,045 hours (fourth quarter) and 4,410 hours (upper 5\%) - it can be concluded that outliers are indeed responsible for the distorted effect on the average. The lower quartile (13 hours/month), median (48 hours/month) and upper quartile (169 hours/month) are therefore suggested as estimates for benchmarking under-, average-, and top downtime performance.

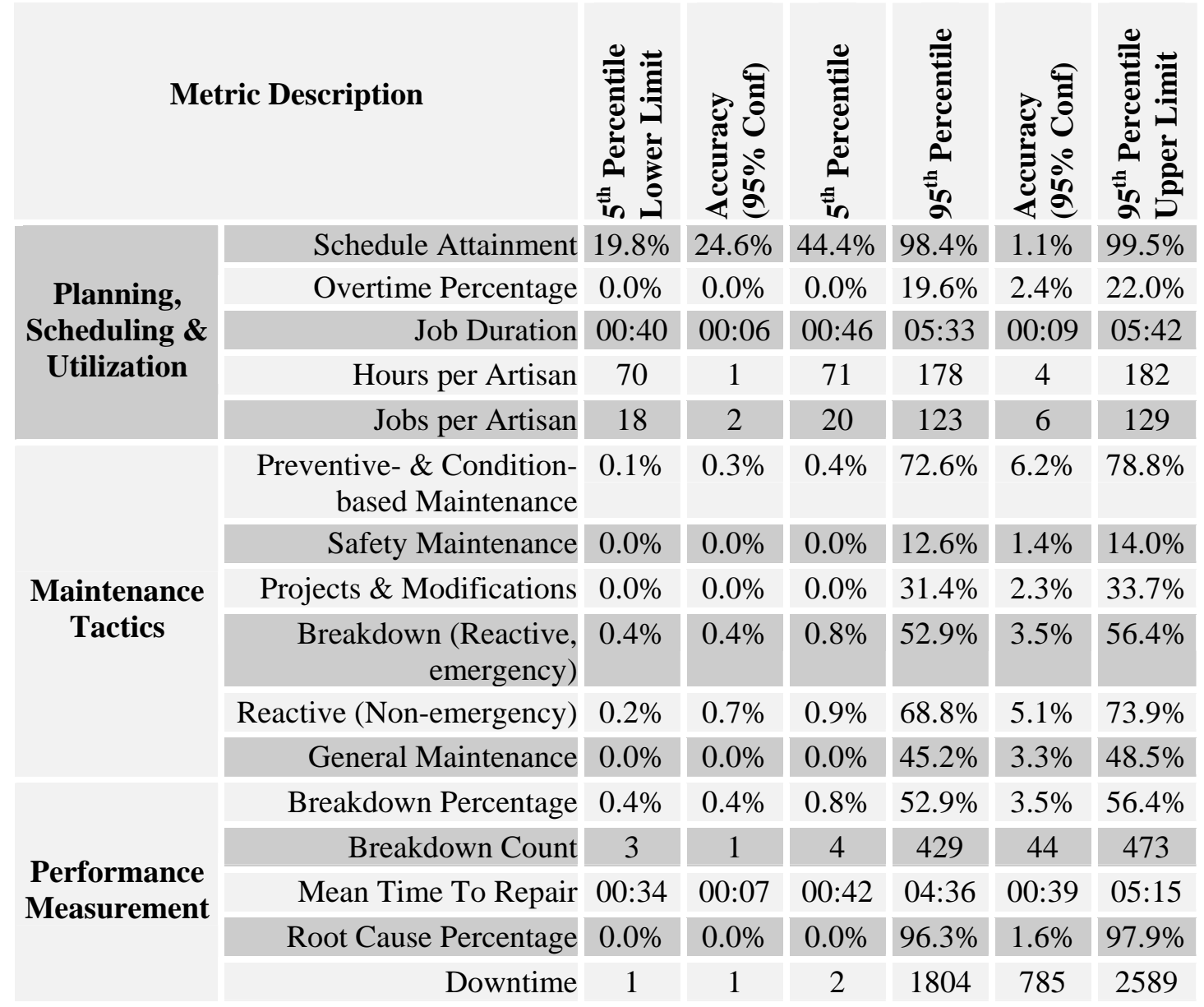

Table 4: Accuracy Limits and Intervals for the $5^{\text {th }}$ - and $95^{\text {th }}$-percentiles

\subsection{Accuracies}

The accuracy on the $5^{\text {th }}$-, $50^{\text {th }}$-, and $95^{\text {th }}$-percentiles and the lower $\left(25^{\text {th }}\right.$-percentile) and upper ( $75^{\text {th }}$-percentile) quartiles are calculated. Kendall and Stuart's [14] approach was followed for the calculation of the accuracies. The advantage of this approach is that it is based on order statistics, and is thus distribution-free and insensitive to outliers. For the $5^{\text {th }}$ - and $95^{\text {th }}$-percentiles, as well as the lower and upper quartiles, one-sided 95\% confidence intervals were calculated, with two-sided confidence intervals for the $50^{\text {th }}$-percentile (median). Accuracies for the $5^{\text {th }}-, 25^{\text {th }}$ - 
(lower quartile), $75^{\text {th }}$ - (upper quartile) and $95^{\text {th }}$-percentiles can be interpreted as follows: it is $95 \%$ certain that the $5^{\text {th }}$ - and $25^{\text {th }}$-percentiles of the population will be greater than the lower confidence limit, while it is $95 \%$ certain that the $75^{\text {th }}$ - and $95^{\text {th }}$ percentiles will be less than the upper confidence limit. For the $50^{\text {th }}$-percentile it is 95\% certain that it will fall between its lower and upper confidence limits. The accuracies for the $5^{\text {th }}$ - and $95^{\text {th }}$-percentiles are shown in Table 4 , for the lower quartile and upper quartile in Table 5 , and for the $50^{\text {th }}$-percentile/median in Table 6. Reasons for poor accuracies are the relatively small sample size and variations in maintenance procedures and data recording at the sample companies. There is also proof of extreme recordings (outliers) affecting the $5^{\text {th }}$ - and $95^{\text {th }}$-percentiles, as can be seen by the accuracies of the schedule attainment $5^{\text {th }}$-percentile and downtime $95^{\text {th }}$-percentile, which are $24.6 \%$ and 785 hours respectively.

\begin{tabular}{|c|c|c|c|c|c|c|c|}
\hline Me & tric Description & 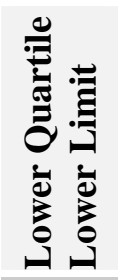 & 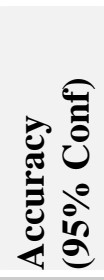 & 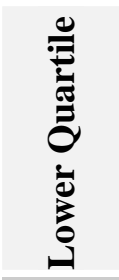 & 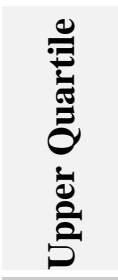 & 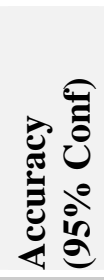 & 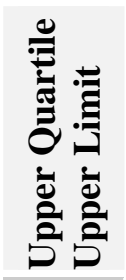 \\
\hline & Schedule Attainment & $68.7 \%$ & $5.4 \%$ & $74.1 \%$ & $90.3 \%$ & $3.2 \%$ & $93.5 \%$ \\
\hline ng, & Overtime Percentage & $0.5 \%$ & $0.3 \%$ & $0.8 \%$ & $8.5 \%$ & $0.7 \%$ & $9.2 \%$ \\
\hline Scheduling \& & Job Duration & 01:23 & 00:04 & $01: 27$ & 03:06 & $00: 10$ & 03:16 \\
\hline Utilization & Hours per Artisan & 93 & 3 & 96 & 148 & 3 & 151 \\
\hline & Jobs per & 37 & 1 & 38 & 77 & 2 & 79 \\
\hline & $\begin{array}{l}\text { Preventive- \& } \\
\text { based Mainten }\end{array}$ & $9.8 \%$ & $0.5 \%$ & $10.3 \%$ & $32.6 \%$ & $1.8 \%$ & $34.4 \%$ \\
\hline & Safety Maintenance & $1 \%$ & $0 \%$ & $.1 \%$ & $.2 \%$ & $6 \%$ & $4.8 \%$ \\
\hline & Projects \& Modifications & $0.6 \%$ & $0.2 \%$ & $0.8 \%$ & $9.6 \%$ & $1.0 \%$ & $10.6 \%$ \\
\hline $\begin{array}{l}\text { antenane } \\
\text { Tactics }\end{array}$ & $\begin{array}{l}\text { Breakdown (Reactive, } \\
\text { emergency) }\end{array}$ & $5.2 \%$ & $0.6 \%$ & $5.8 \%$ & $27.3 \%$ & $1.4 \%$ & $28.7 \%$ \\
\hline & Reactive (Non-emergency) & $12.5 \%$ & $0.7 \%$ & $13.2 \%$ & $43.2 \%$ & $1.7 \%$ & $44.9 \%$ \\
\hline & General Maintenance & $1.5 \%$ & $0.5 \%$ & $2.0 \%$ & $19.8 \%$ & $1.4 \%$ & $21.2 \%$ \\
\hline & Change Overs \& Setting & $0.0 \%$ & $0.0 \%$ & $0.0 \%$ & $5.6 \%$ & $1.5 \%$ & $7.1 \%$ \\
\hline & Breakdown Percentage & $5.2 \%$ & $0.6 \%$ & $5.8 \%$ & $27.3 \%$ & $1.4 \%$ & $28.7 \%$ \\
\hline & Breakdown Count & 16 & 1 & 17 & 110 & 14 & 124 \\
\hline $\begin{array}{l}\text { Pertormance } \\
\text { Measurement }\end{array}$ & Mean Time To Repair & $01: 15$ & 00:04 & 01:19 & $02: 50$ & $00: 10$ & 03:00 \\
\hline & Root Cause P & $0.0 \%$ & $0.0 \%$ & $0.0 \%$ & $62.5 \%$ & $8.9 \%$ & $71.4 \%$ \\
\hline & Downtime & 11 & 2 & 13 & 169 & 17 & 186 \\
\hline
\end{tabular}

Table 5: Accuracy Limits and Intervals for the lower- and upper quartiles 


\begin{tabular}{|c|c|c|c|c|c|}
\hline \multicolumn{2}{|c|}{ Metric Description } & \multirow{2}{*}{ 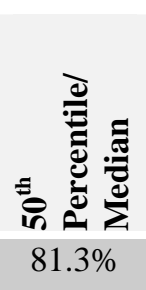 } & \multirow{2}{*}{ 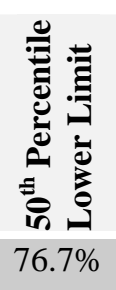 } & \multirow{2}{*}{ 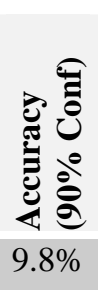 } & \multirow{2}{*}{ 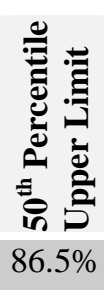 } \\
\hline \multirow{5}{*}{$\begin{array}{l}\text { Planning, } \\
\text { Scheduling \& } \\
\text { Utilization }\end{array}$} & Schedule Attainment & & & & \\
\hline & Overtime Percentage & $4.2 \%$ & $3.6 \%$ & $1.1 \%$ & $4.7 \%$ \\
\hline & Job Duration & 02:11 & 02:06 & $00: 12$ & 02:18 \\
\hline & Hours per Artisan & 117 & 115 & 6 & 121 \\
\hline & Jobs per Artisan & 52 & 50 & 5 & 55 \\
\hline \multirow{7}{*}{$\begin{array}{l}\text { Maintenance } \\
\text { Tactics }\end{array}$} & $\begin{array}{l}\text { Preventive- \& Condition- } \\
\text { based Maintenance }\end{array}$ & $18.4 \%$ & $17.0 \%$ & $2.3 \%$ & $19.3 \%$ \\
\hline & Safety Maintenance & $1.1 \%$ & $0.9 \%$ & $0.5 \%$ & $1.4 \%$ \\
\hline & Projects \& Modifications & $3.6 \%$ & $2.9 \%$ & $1.4 \%$ & $4.3 \%$ \\
\hline & $\begin{array}{l}\text { Breakdown (Reactive, } \\
\text { emergency) }\end{array}$ & $12.3 \%$ & $11.1 \%$ & $2.4 \%$ & $13.5 \%$ \\
\hline & $\begin{array}{l}\text { Reactive (Non- } \\
\text { emergency) }\end{array}$ & $26.3 \%$ & $24.4 \%$ & $4.5 \%$ & $28.9 \%$ \\
\hline & General Maintenance & $9.2 \%$ & $7.8 \%$ & $2.3 \%$ & $10.1 \%$ \\
\hline & Change Overs \& Settings & $1.6 \%$ & $1.2 \%$ & $0.9 \%$ & $2.1 \%$ \\
\hline \multirow{5}{*}{$\begin{array}{l}\text { Performance } \\
\text { Measurement }\end{array}$} & Breakdown Percentage & $12.3 \%$ & $11.1 \%$ & $2.4 \%$ & $13.5 \%$ \\
\hline & Breakdown Count & 47 & 38 & 16 & 54 \\
\hline & Mean Time To Repair & 02:09 & 02:01 & $00: 12$ & 02:13 \\
\hline & Root Cause Percentage & $0.0 \%$ & $0.0 \%$ & $2.2 \%$ & $2.2 \%$ \\
\hline & Downtime & 48 & 37 & 23 & 60 \\
\hline
\end{tabular}

Table 6: Accuracy Limits and Intervals for the $50^{\text {th }}$-percentile/median

\section{CONCLUSIONS}

Although the sample was not random, and was based on the premises of a single asset management service provider, the figures probably differ only marginally from those of the full population of maintenance departments in the sectors listed in this paper.

In comparison with published benchmarks of recent years, local maintenance departments are falling short with regard to preferred maintenance tactics. Campbell [6] suggests a 35:65 ratio for unplanned to planned maintenance, while the Thomas Marketing Information Centre (cited by Mitchell [3]) and Bahrami (cited by Mitchell [3]) suggest ratios of 15:85 and 30:70 respectively (Figure 5). The averages of $24.1 \%$ and $58.1 \%$ on planned and unplanned maintenance respectively (as shown in section 4.2) currently achieved by local industry are way off in comparison with the above standards, showing that South African enterprises are still spending most of their time on reactive maintenance. 


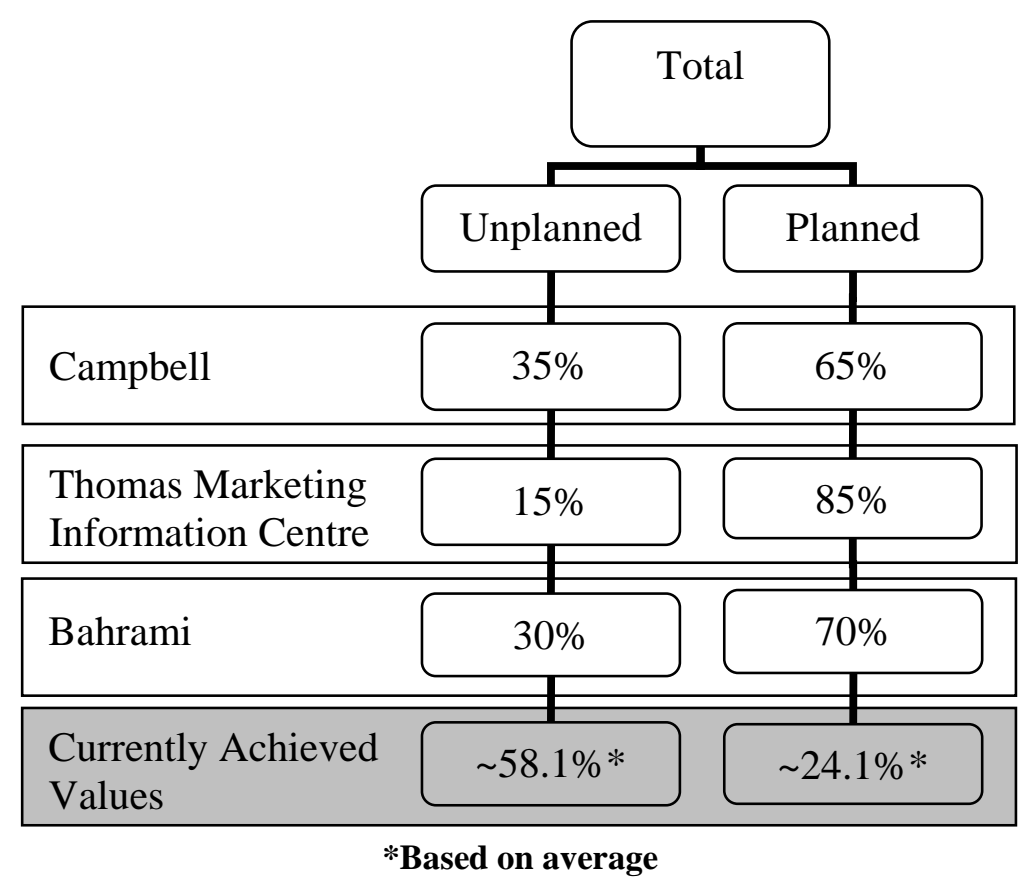

Figure 5: Comparison between published benchmarks and currently achieved values

Under-performance in analysis of the root causes of breakdown contributes to the negative planned to unplanned maintenance ratio highlighted above. Based on the Root Cause Percentage (refer to Table 3), 50\% of industry does not analyse breakdown occurrences to root cause level, illustrating industry's tendency towards reactive maintenance.

This suggests that the local maintenance workforce is efficient but not effective. On average, artisans are utilized between $62 \%$ and $70 \%$ per month (Figure 6), based on the average 121 hours worked per month and a 40- to 45-hour work week (as outlined by the Basic Conditions of Employment Act [15]). Artisan utilization is therefore in line with the $65 \%$ standard suggested by some industry experts [8]. Based on the average percentage of unplanned maintenance (58.1\%) and the relatively high artisan utilization (62-70\%), it follows that the local maintenance workforce is efficient, but not effective - that is, they are performing the wrong maintenance activities well.

The results shown for schedule attainment in Table 1 are positive. An average of $78.7 \%$ of scheduled maintenance is completed within four weeks from the intended date, while a quarter (upper quartile) of industry is achieving more than $90.3 \%$. Since schedule attainment is a measure of work planning and control performance, we conclude that companies making use of a formal maintenance management system as in the case of the sample - will achieve levels of performance conforming to current published standards (refer to section 4.1). 


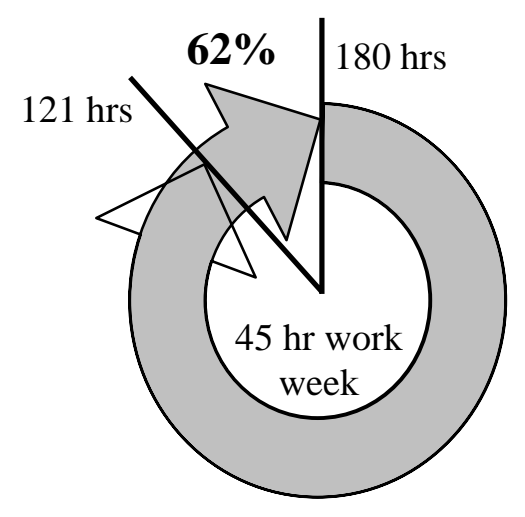

(a)

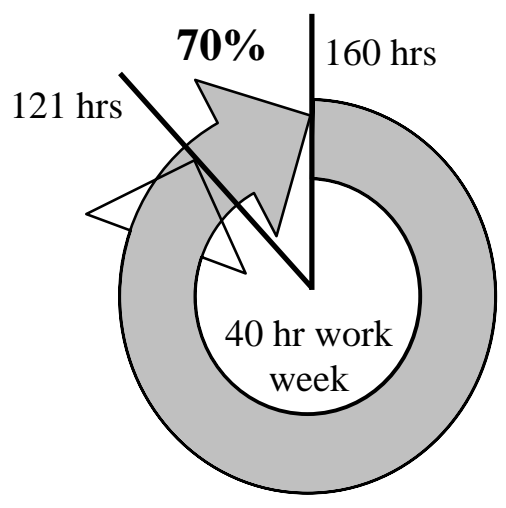

(b)

Figure 6: Labour utilization for (a) 45-hour and (b) 40-hour work week

Based on the downtime results in section 4.3, it is clear that this important measure of lost production time is not satisfactorily recorded. Although the intention of this study was not to investigate recording practices, probable reasons for the poor recording of downtime could be: confusing or unclear definitions of breakdown manhours (breakdown job duration) and of downtime hours (lost production duration); ineffective procedures; or parallel/independent performance measurement systems run by both the production and engineering departments.

Maintenance managers should find the indicators presented in this paper useful for benchmarking their maintenance department's performance against others in the local industry. The percentiles can be used to determine a maintenance department's position relative to the industry standard, allowing for targets to be set to drive improvement initiatives.

\section{REFERENCES}

[1] Woodhouse, J. (2001), Asset Management, Woodhouse Partnership Ltd. Available http://www.twpl.co.uk/

[2] Wilson, A. (1999), Asset Maintenance Management: A Guide to Developing Strategy and Improving Performance, Conference Communication, Surrey, UK

[3] Mitchell, J.S. (2002). Physical Asset Management Handbook. Houston: Clarion Technical Publishers. Available from:

[4] Yam, R.C.M., Tse, P., Ling, L. and Fung, F. (2000). Enhancement of maintenance management through benchmarking, Journal of Quality in Maintenance Engineering, 6(4), pp. 224-240.

[5] Jooste, J.L. (2003), Asset Performance Management Model. Thesis (MSc.Eng), Stellenbosch University.

[6] Campbell, J.D. (1995), Uptime: Strategies for Excellence in Maintenance Management, Productivity Press, Portland, Oregon.

[7] Chin, K.S., Pun, K.F., Lau, C.S. and Lau, H. (2001) Performance improvement of international roaming service, Benchmarking: An International Journal, 8(2), pp. 120-131. 
[8] www.pragma.co.za

[9] Hudson, M., Smart, A. and Bourne, M. (2001). Theory and practice in SME performance measurement systems, International Journal of Operations and Production Management, 21(8), pp. 1096-1115.

[10] Sohal, A.M., Schroder, R., Uliana, E.O. and Maguire, W. (2001), Adoption of AMT by South African manufacturers, Integrated Manufacturing, 12(1), pp. $15-34$.

[11] http://unstats.un.org/unsd/cr/registry/regcst.asp?Cl=17 [6-Nov-2005].

[12] Keller, G. and Warrack, B. (2003), Statistics for Management and Economics, Brooks/Cole - Thomson Learning, Pacific Grove, CA. pp.92-115.

[13] Devore, J.L. and Farnum, N.R. (1999). Applied Statistics for Engineers and Scientists. Brooks/Cole - Thomson Learning, Pacific Grove, CA.

[14] Kendall, M.G. and Stuart, A. (1969). The Advanced Theory of Statistics, Vols. 1 and 2. Third Edition. London: Charles Griffin and Company Limited.

[15] South African Department of Labour. (1997). Basic Conditions of Employment Act, National Publishing (Pty) Ltd, Clareinch. 